\title{
Characterization and Iron Removal Treatment of Ion-Adsorption Rare Earth Tailings in Southern China
}

\author{
Yongqing Wang, Xin Nie, Qibing Chang*, Huayin Liang, \\ Xiaozhen Zhang, Jian-Er Zhou \\ School of Materials Science and Engineering, Jingdezhen Ceramic Institute, Jingdezhen, China \\ Email: "changqb1258@hotmail.com
}

Received 12 February 2016; accepted 8 March 2016; published 11 March 2016

Copyright (C) 2016 by authors and Scientific Research Publishing Inc.

This work is licensed under the Creative Commons Attribution International License (CC BY). http://creativecommons.org/licenses/by/4.0/

c) (i) Open Access

\begin{abstract}
The ion-adsorption rare earth tailings have become a serious environmental pollution in Southern China, yet the potential of their economical value has not been fully exploited. In this work, the chemical and mineral compositions of the ion-adsorption rare earth tailings were characterized by Mineral Liberation Analyze (MLA) and XRF. The results show that $91.98 \mathrm{wt} \%$ of the tailings are composed of kaolinite and quartz, latter of which was removed by the sieving method. The other minor minerals contain feldspar, biotite, muscovite, titanomagnetite and limonite. Amongst these, the iron-bearing minerals are mostly found in the titanomagnetite and limonite which can be mostly removed by using a periodic high-gradient magnetic separator with a magnetic induction of 0.6 Tesla. The $\mathrm{Fe}_{2} \mathrm{O}_{3}$ content of the tailings changed from $2.11 \mathrm{wt} \%$ to $1.06 \mathrm{wt} \%$ after the sorting process, which met the Chinese national standard of TC-3 grade raw materials for ceramic industry applications. The $\mathrm{Fe}_{2} \mathrm{O}_{3}$ content in kaolinite was further decreased after $\mathrm{Na}_{2} \mathrm{~S}_{2} \mathrm{O}_{4}$ treatment.
\end{abstract}

\section{Keywords}

Tailings, Resource, Rare Earth, Iron Removal, Kaolinite, Magnetic Separation

\section{Introduction}

Rare earth elements (REEs) have become vital and indispensable components of many advanced products, devices and technologies. The production of rare earth minerals in China increased by an average of $40 \%$ annually between 1978 and 1989, and had provided more than 90\% of the world's supply since 2001 [1]-[3]. Ion-adsorp-

${ }^{*}$ Corresponding author.

How to cite this paper: Wang, Y.Q., Nie, X., Chang, Q.B., Liang, H.Y., Zhang, X.Z. and Zhou, J.-E. (2016) Characterization and Iron Removal Treatment of Ion-Adsorption Rare Earth Tailings in Southern China. Journal of Minerals and Materials Characterization and Engineering, 4, 127-134. http://dx.doi.org/10.4236/immce.2016.42012 
tion rare earth deposition was firstly discovered in Ganzhou, Southern China, in 1970. Unlike other rare earth minerals which are in solid state mineral phase and tend to be associated with the radioactive elements uranium and thorium, ion-adsorption rare earth minerals occur at a simple trivalent cationic state, which is simply adsorbed onto clays and could be readily extracted by a simple leaching technique with an aqueous electrolyte solution via anion-exchange process [4]. The extraction of ion-adsorption rare earth is carried out by surface/ mountain-top mining followed by tank or heap leaching with sodium chloride ammonium sulfate solution.

Ion-adsorption rare earth deposition has a relatively low REEs concentration ranging from 10 to a few hundred parts per million by weight [4]. Using heap leaching techniques, it is estimated that for the production of 1 tons (t) rare earth oxide, 2000 tons tailings are disposed into adjacent valleys and streams. Due to this, the rare earth miners in Ganzhou region have generated 191 million tons of tailings [5]. These hazardous tailings are a major environmental concern causing increased water and soil loss, deterioration of water quality and potentially other geological disasters. Therefore, the re-utilization of the tailings not only reduces their impact of environmental pollution but also can be used to develop highly valued end-products for the associated industries [3]. To realize it, the tailings should be characterized and pre-treated before their re-utilization.

In the present work, the chemical and mineral compositions of the ion-adsorbed rare earth tailings from the Southern China were analyzed in order to determine the feasibility of the tailings as raw materials for the ceramic industry. The treatments of the tailings, such as sieving, iron removal treatment, were also considered.

\section{Materials and Methods}

The tailings were collected from the ion-adsorption rare earths area in Ganzhou, Southern China. Representative samples were prepared by following Chinese standard method of mixing (China Standard Specification, GB2007.1-87).

The chemical element analysis of samples was performed with an XRF spectrometer (PANalytical AxiosmAX, Netherland).

The bulk mineral composition was performed with Mineral Liberation Analyzer (MLA 650, Czech Republic), which was equipped with environment SEM (FEI, Quanta 650), EDS (Bruker Quantax 200) and mineral parameters automatic analysis software of (MLA2.9). For preparation of grain mounts in epoxy blocks, $10-100 \mathrm{~g}$ of dried mineral sands is required. Aliquots of $10-20 \mathrm{~g}$ of a sample will be mixed with pure graphite powder to prevent particle cohesion and embedded in epoxy blocks. The preferred diameter of the round blocks is $30 \mathrm{~mm}$, diameters of $25 \mathrm{~mm}$. The other operational parameters are reported in Reference [6].

In the pre-treatment processes, the tailings was sieved sequentially by the copper standard sieves with the sieve sizes of $0.8 \mathrm{~mm}, 0.4 \mathrm{~mm}, 0.25 \mathrm{~mm}, 0.12 \mathrm{~mm}, 0.075 \mathrm{~mm}, 0.043 \mathrm{~mm}$. The $-0.043 \mathrm{~mm}$ fraction of the tailings was used for the process of iron removal. Firstly, the sample was fed to the high gradient magnetic separator (SSS-I-145) [7] [8] to remove magnetite and ilmenite, followed by a bleaching process of the remained samples (fine kaolinite) using hydrogen peroxide [9] or sodium dithionite [10] as the leaching agent.

\section{Results and Discussion}

\subsection{Characterization of the Tailings}

\subsubsection{Chemical Composition of Tailings Characterized by XRF}

The chemical composition of the tailings sample was characterized by XRF. The data is presented in Table 1. The rich chemical composition in oxides in mine tailing are $\mathrm{SiO}_{2}(78.32 \mathrm{wt} \%), \mathrm{Al}_{2} \mathrm{O}_{3}(17.50 \mathrm{wt} \%)$ and $\mathrm{Fe}_{2} \mathrm{O}_{3}$ (2.11 wt\%). However, $\mathrm{Fe}_{2} \mathrm{O}_{3}$ is not what we want because it gives a brown color to ceramics. Therefore, iron removal is required to the tailings until the $\mathrm{Fe}_{2} \mathrm{O}_{3}$ content is under the maximum limit (1.8 wt\%) for ceramic applications according to the Chinese standard GB/T 14563-1993.

\subsubsection{Mineral Composition of Tailings Characterized by MLA}

The tailings are the mixtures of many minerals. Generally, the minerals can be distinguished out by Mineral Liberation Analyzer (MLA). Table 2 shows the mineral composition of the tailings. Quartz and kaolinite are the major minerals of the tailings, which take up $91.98 \mathrm{wt} \%$ of the tailings. Quartz and kaolinite are commonly utilized in ceramic application. Therefore, they can be of industrial interest after a proper treatment processing. The other silicates, such as feldspar, biotite, muscovite and amphibole, are also generally used as sintering aid in ce- 
Table 1. Chemical composition of the tailings measured by XRF.

\begin{tabular}{cccccccccc}
\hline Composition & $\mathrm{SiO}_{2}$ & $\mathrm{Al}_{2} \mathrm{O}_{3}$ & $\mathrm{Fe}_{2} \mathrm{O}_{3}$ & $\mathrm{TiO}_{2}$ & $\mathrm{~K}_{2} \mathrm{O}$ & $\mathrm{Na}_{2} \mathrm{O}$ & $\mathrm{CaO}$ & $\mathrm{MgO}$ \\
\hline Content $(\mathrm{wt} \%)$ & 78.32 & 17.50 & 2.11 & 0.38 & 1.21 & 0.43 & 0.22 & 1.33 \\
\hline
\end{tabular}

Table 2. Mineral composition of the tailings.

\begin{tabular}{cccccc}
\hline Mineral & Content wt $\%$ & Mineral & Content wt $\%$ & Mineral & Content wt $\%$ \\
\hline Kaolinite & 42.29 & Monazite & 0.01 & Colloidal rare earth & 0.01 \\
Quartz & 49.69 & Xenotime & 0.01 & Titanomagnetite & 1.10 \\
Feldspar & 3.90 & Parisite & 0.01 & Limonite & 0.29 \\
Diopside & 0.01 & Rutile & 0.09 & Ilmenite & 0.13 \\
Muscovite & 0.68 & Leucoxene & 0.10 & Iron titanite & 0.04 \\
Biotite & 1.36 & Pyrite & 0.01 & Remainder & 0.14 \\
Amphibole & 0.11 & Galena & 0.01 & Total & 100 \\
\hline
\end{tabular}

ramic applications. The iron- and titanium-contained minerals include titanomagnetite, limonite, pyrite, ilmenite, rutile and leucoxene, which make up $1.72 \mathrm{wt} \%$ of the tailings. The total content of rare earth minerals is only $0.04 \mathrm{wt} \%$, which include monazite, xenotime, parisite and colloidal rare earth.

The SEM images of the minerals are shown in Figures 1-5.

Figure 1 shows the SEM images of kaolinite particles in the tailings. The kaolinite particles are observed as aggregation of microcrystalline flakes, which is consistent with the results in these references [9] [11]-[13]. The kaolinite grains are irregular in shapes. The particle size of the kaolinite grains is estimated in the range of 50 $300 \mu \mathrm{m}$. It is also found that monazite, biotite and magnetite are embedded in the kaolinite grains. The chemical compositions and their concentrations of kaolinite measured by EDS are $\mathrm{Fe}_{2} \mathrm{O}_{3} 0.57 \%, \mathrm{TiO}_{2} 0.10 \%, \mathrm{Al}_{2} \mathrm{O}_{3}$ $39.24 \%, \mathrm{SiO}_{2} 58.36 \%, \mathrm{~K}_{2} \mathrm{O} 0.12 \%, \mathrm{CaO} 0.19 \%$ and $\mathrm{MgO} 1.05 \%$ (in weight percent). Specially, it has been reported that the magnetite grains embedded in the kaolinite grains may not be removed by magnetic method [8] or chemical method [9] [10]. Therefore, $0.24 \mathrm{wt} \% \mathrm{Fe}_{2} \mathrm{O}_{3}$ of the tailings $(0.57 \% * 0.42$ (kaolinite content in tailings) $=0.24 \%$ ) still remain in the tailings even if after iron removal.

The chemical compositions and their concentrations of feldspar measured by EDS are $\mathrm{K}_{2} \mathrm{O} 7.50 \%, \mathrm{Na}_{2} \mathrm{O}$ $4.62 \%, \mathrm{CaO} 0.51 \%, \mathrm{Al}_{2} \mathrm{O}_{3} 19.59 \%, \mathrm{SiO}_{2} 67.58 \%$ and $\mathrm{FeO} 0.20 \%$ (in weight percent). Fe element is incorporated in the crystal lattice of feldspar. Most of feldspar has been weathered into kaolinite.

Quartz is the major mineral in the tailings according to the data in Table 2. Figure 2 shows the SEM images of the quartz particles. As can be seen, the quartz is associated with magnetite, muscovite, or parisite.

Magnetite is the main iron-bearing minerals in the tailings. EDS results show the chemical elements of the magnetite mineral include Fe 66.28\%, Ti 3.18\%, Mn 0.51\%, Zn 0.49\%, K 0.01\%, Al 0.95\%, Si 0.67\% and O $27.92 \%$ (in weight percent).

The SEM image of magnetite particles associated with the $\mathrm{TiO}_{2}$ is shown in Figure 3(A). The titanomagnetite mineral forms a grid mark pattern in the cross-section of magnetite grain. Figure 3 shows that it is hard to separate titanomagnetite from magnetite by sieving separation method. Figure 3(B) shows the image of the magnetite associated kaolinite. In fact, Figure 1(D) and Figure 3(B) show that kaolinite and magnetite have the similar associated mineral structure. This associated structure results in the difficulty in the separation of magnetite from kaolinite.

Limonite is another iron-bearing mineral found in the tailings. EDS results show the chemical elements of the magnetite mineral include $\mathrm{Fe} 53.19 \%$, Ti $0.52 \%$, Mn 0.62\%, Zn 0.08\%, Ca 0.24\%, Al 3.57\%, Si 3.05\%, Cr $0.11 \%, \mathrm{~S} 0.44 \%$ and $\mathrm{O} 38.12 \%$ (in weight percent).

Figure 4 shows the SEM image of limonite particles. Limonite particles found to be are granular and dustlike. The particle size is in the range of $0.1 \mu \mathrm{m}-0.08 \mathrm{~mm}$. $80 \mathrm{wt} \%$ of limonite has particle sizes of less than 0.01 $\mathrm{mm}$. And most of the dust-like limonite particles are mixed with kaolinite.

The chemical composition of ilmenite in the sample is $52.38 \% \mathrm{TiO}_{2}, 41.23 \% \mathrm{FeO}$ and $6.40 \% \mathrm{MnO}$ (in weight 

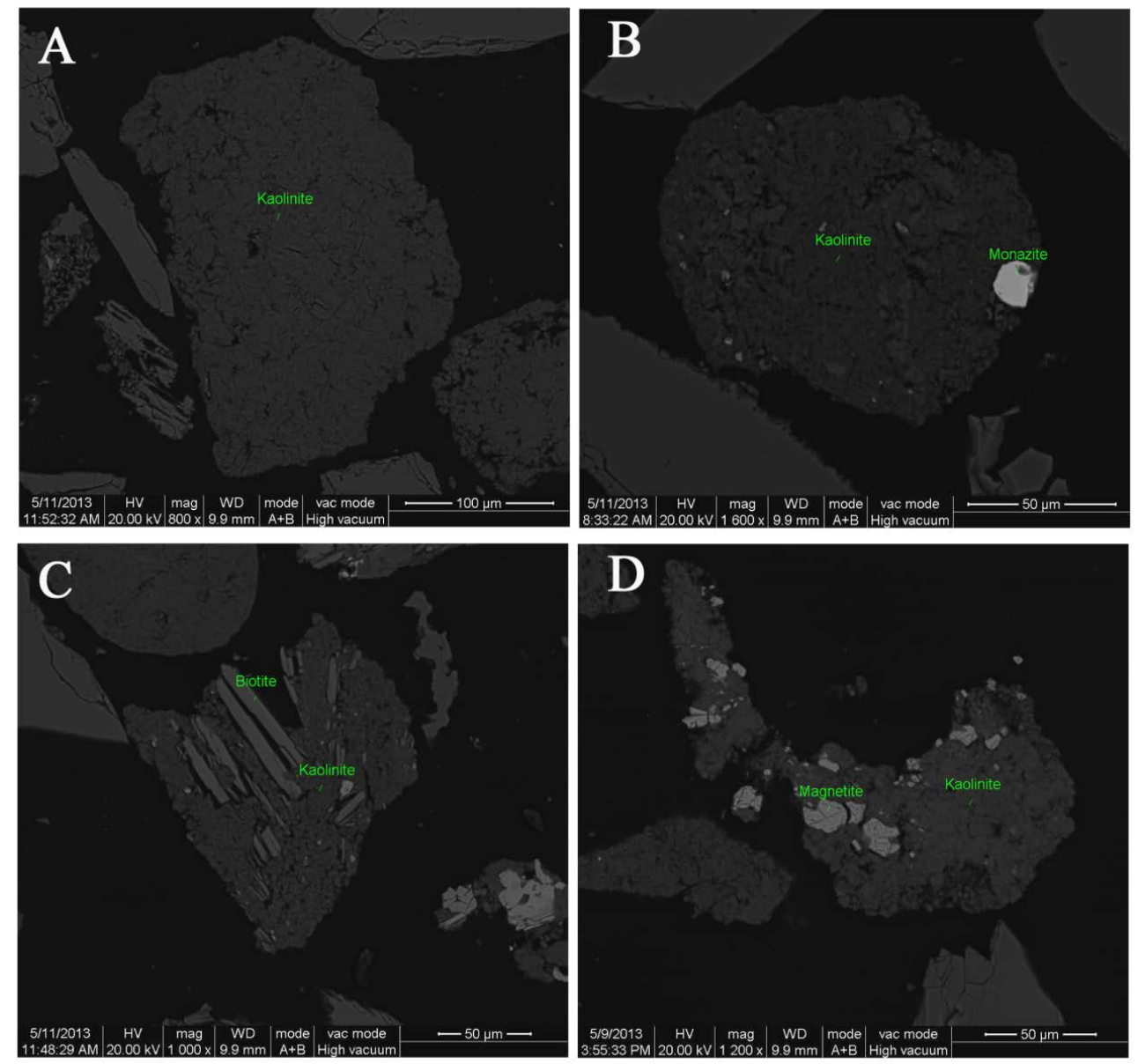

Figure 1. SEM images of kaolinite: (A) single grains; (B) embedded monazite; (C) embedded biotite; (D) embedded magnetite.

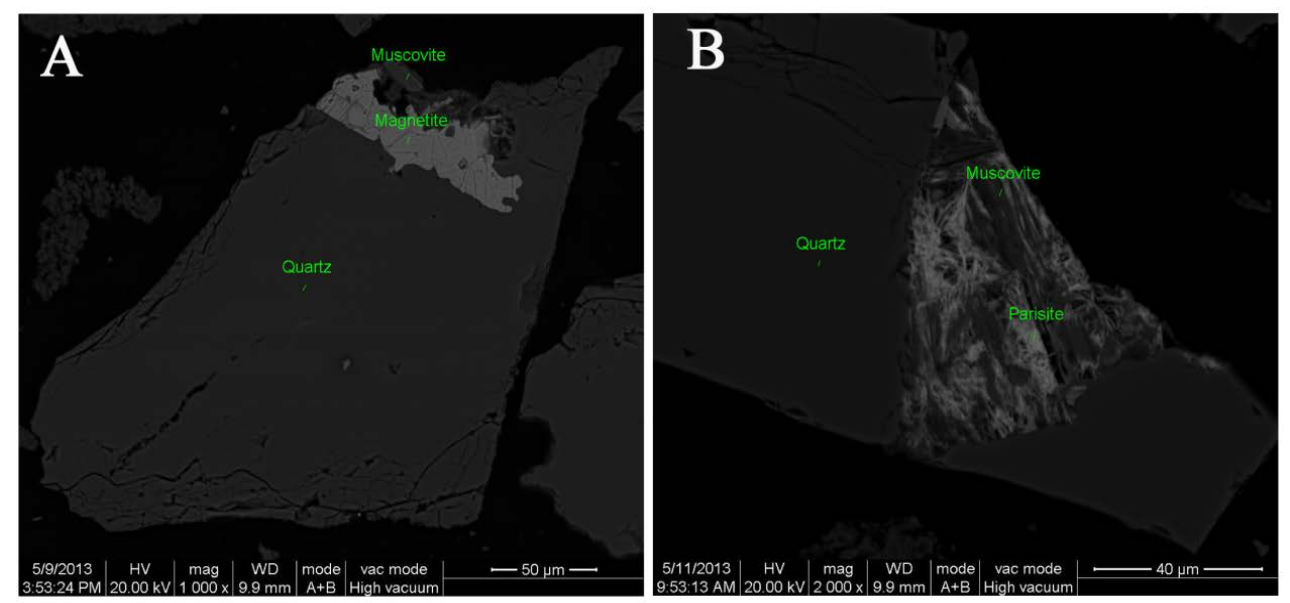

Figure 2. SEM images of the associated minerals of (A) quartz, magnetite and muscovite; (B) quartz, muscovite and parasite.

percent). Ilmenite in the tailings is granular and very fine. The particles size distribution is in the range of 0.1 $\mu \mathrm{m}-0.15 \mathrm{~mm}$. Ilmenite grains are mostly associated with magnetite, kaolinite or xenotimeetc, as shown in Figure 5 . 


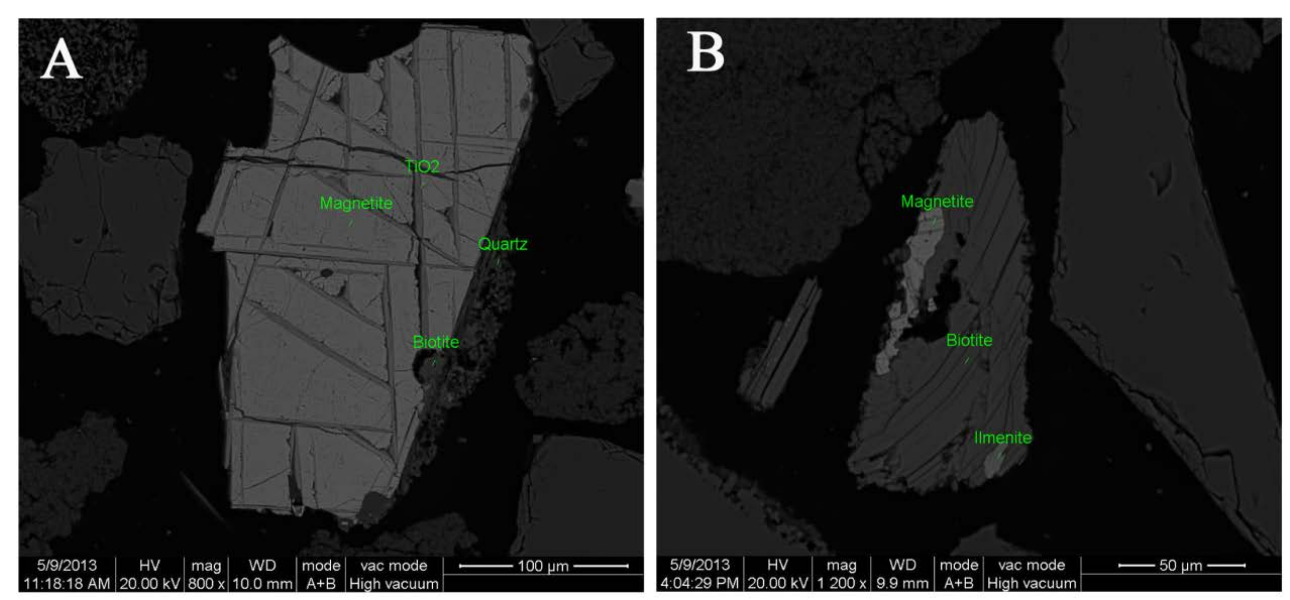

Figure 3. SEM images of the associated minerals of (A) magnetite and $\mathrm{TiO}_{2}$; (B) magnetite and kaolinite.

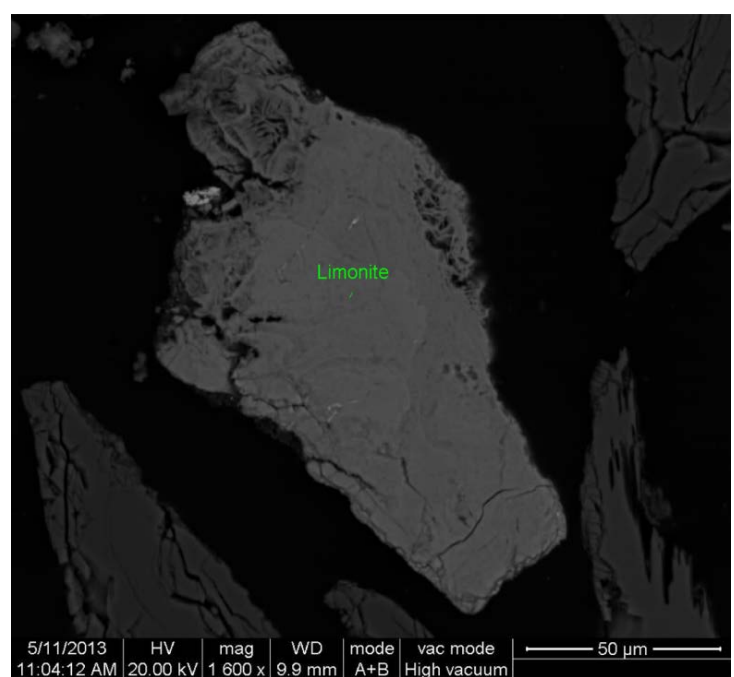

Figure 4. SEM image of limonite.

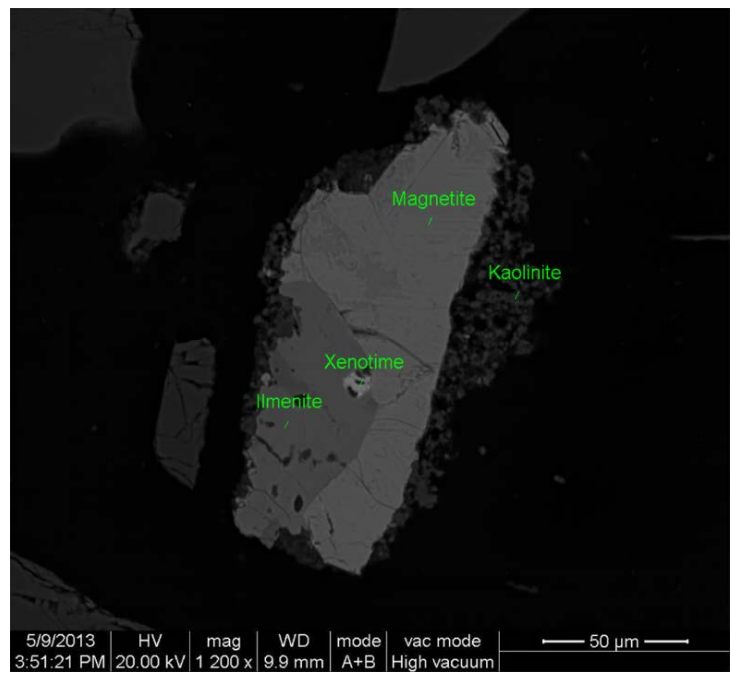

Figure 5. SEM images of ilmenite. 


\subsection{Pre-Treatment of the Tailings}

The data in Table 2 show that most of the mineral in the tailing can be utilized in ceramic industry except of $\mathrm{Fe}_{2} \mathrm{O}_{3}$. Therefore, the pre-treatment of the tailings before re-utilization is mostly iron removal.

\subsubsection{Fe Element Distribution}

Kaolinite and quartz together make up $91.98 \%$ of the ion-adsorption rare earth tailings. It implies that the tailings can be re-utilized in ceramic application if the $\mathrm{Fe}$ content is less than $1.8 \%$ according to the requirement of TC-3 grade in the national standard GB/T 14563-1993. However, the content of $\mathrm{Fe}_{2} \mathrm{O}_{3}$ in the tailings is $2.11 \%$, thus, further treatment to remove the iron is required.

Table 3 shows the distribution of Fe element in the tailings. It shows that titanomagnetite, kaolinite and limonite are the main Fe-bearing minerals in the tailings. Only titanomagnetite and limonite can be removed by magnetic separator methods. If titanomagnetite and limonite are removed, the $\mathrm{Fe}$ content in the tailings decreased to $1.23 \%$, which meets the requirement of the standard of TC-3 grade for ceramic industry applications.

To ascertain the various particle sizes, the particle size distribution of the tailings is characterized by standard sieves method. Table 4 shows the particle size distribution and the grade of $\mathrm{SiO}_{2}, \mathrm{Al}_{2} \mathrm{O}_{3}, \mathrm{Fe}_{2} \mathrm{O}_{3}$ and $\mathrm{TiO}_{2}$ in the distribution. The $+0.4 \mathrm{~mm}$ and $-0.043 \mathrm{~mm}$ fraction are the main of the particle size distribution. The grade of $\mathrm{SiO}_{2}$ decreases with decreasing particle size. The grade of $\mathrm{SiO}_{2}$ in the $+0.4 \mathrm{~mm}$ fraction is larger than $91.46 \%$, implying that coarse grains are quartz and they can be separated by $0.4 \mathrm{~mm}$ sieve. Correspondingly, the fine grains $(<0.043 \mathrm{~mm})$ are kaolinite because the grade of $\mathrm{Al}_{2} \mathrm{O}_{3}$ increases with decreasing particle size. The change

Table 3. Distribution of Fe element in the tailings.

\begin{tabular}{ccccc}
\hline Mineral & $\begin{array}{c}\text { Mineral content in tailings } \\
/ \text { wt } \%\end{array}$ & $\begin{array}{c}\text { Fe content in minerals/ } \\
\text { wt } \%\end{array}$ & $\begin{array}{c}\text { Fe content in tailings/ } \\
\text { wt } \%\end{array}$ & $\begin{array}{c}\text { Ratio of Fe distribution/ } \\
\text { wt } \%\end{array}$ \\
Kaolinite & 42.29 & 0.57 & 0.24 & 16.99 \\
Quartz & 49.69 & 0.17 & 0.08 & 5.98 \\
Feldspar & 3.90 & 0.16 & 0.01 & 0.43 \\
Titanomagnetite & 1.10 & 66.28 & 0.73 & 51.73 \\
Limonite & 0.29 & 53.19 & 0.15 & 10.85 \\
Ilmenite & 0.13 & 32.07 & 0.04 & 2.98 \\
Muscovite & 0.68 & 2.24 & 0.02 & 1.08 \\
Biotite & 1.36 & 10.34 & 0.14 & 1.41 \\
Total & 99.45 & - & & 9.98 \\
\hline
\end{tabular}

Table 4. Particle size distribution of the tailings and the quality of $\mathrm{SiO}_{2}, \mathrm{Al}_{2} \mathrm{O}_{3}, \mathrm{Fe}_{2} \mathrm{O}_{3}$ and $\mathrm{TiO}_{2}$.

\begin{tabular}{|c|c|c|c|c|c|c|c|c|c|}
\hline \multirow{2}{*}{$\begin{array}{l}\text { Particles size } \\
\qquad / \mathrm{mm}\end{array}$} & \multirow{2}{*}{$\begin{array}{l}\text { Yield } \\
/ \%\end{array}$} & \multicolumn{4}{|c|}{ Grade/\% } & \multicolumn{4}{|c|}{ Recovery rate/\% } \\
\hline & & $\mathrm{SiO}_{2}$ & $\mathrm{Al}_{2} \mathrm{O}_{3}$ & $\mathrm{Fe}_{2} \mathrm{O}_{3}$ & $\mathrm{TiO}_{2}$ & $\mathrm{SiO}_{2}$ & $\mathrm{Al}_{2} \mathrm{O}_{3}$ & $\mathrm{Fe}_{2} \mathrm{O}_{3}$ & $\mathrm{TiO}_{2}$ \\
\hline 0.8 & 19.1 & 98.44 & 0.91 & 0.31 & 0.05 & 23.99 & 0.99 & 2.96 & 2.85 \\
\hline$-0.8 \sim+0.4$ & 7.45 & 91.46 & 6.24 & 1.22 & 0.15 & 8.69 & 2.65 & 4.54 & 3.34 \\
\hline$-0.4 \sim+0.25$ & 3.49 & 79.55 & 13.28 & 4.02 & 0.59 & 3.54 & 2.64 & 7.01 & 6.15 \\
\hline$-0.25 \sim+0.12$ & 7.01 & 74.19 & 16.99 & 3.81 & 0.62 & 6.64 & 6.79 & 13.35 & 12.98 \\
\hline$-0.12 \sim+0.075$ & 4.15 & 72.70 & 18.90 & 3.30 & 0.72 & 3.85 & 4.47 & 6.85 & 8.93 \\
\hline$-0.075 \sim+0.043$ & 4.81 & 73.17 & 19.41 & 2.91 & 0.76 & 4.49 & 5.33 & 7.00 & 10.92 \\
\hline-0.043 & 53.99 & 70.84 & 25.04 & 2.16 & 0.34 & 48.80 & 77.12 & 58.29 & 54.83 \\
\hline$\sum$ (Crude tailing) & 100 & 78.32 & 17.50 & 2.11 & 0.38 & 100 & 100 & 100 & 100 \\
\hline
\end{tabular}


of the $\mathrm{Fe}_{2} \mathrm{O}_{3}$ grade is in accord with that of $\mathrm{Al}_{2} \mathrm{O}_{3}$. Considering the discussion in section 3.1, it can be concluded that the iron-bearing minerals is mostly mixed with kaolinite. The methods of iron removal from kaolinite reported in reference [8]-[11] can be applied in the tailings.

\subsubsection{Iron Removal by Magnetic Separator}

The $-0.4 \mathrm{~mm}$ fraction of the tailings is treated by a periodic high-gradient magnetic separator (SSS-I-145). The $\mathrm{Fe}$ content of the sorted tailings is measure by XRF. The effect of the magnetic induction on the Fe content is listed in Table 5.

As can be seen, the $\mathrm{Fe}$ grade of the sorted tailings decreases with the increase of the magnetic induction. However, the ratio of iron removal is not proportional to the magnetic induction. The ratio of iron removal increases quickly with the increase of the magnetic induction before the magnetic induction is 0.6 Tesla. And then, the ratio of iron removal increases slightly (4.68\%) when the magnetic induction increases further from $0.6 \mathrm{~T}$ to $1 \mathrm{~T}$. When the magnetic induction is $0.6 \mathrm{~T}$, the Fe grade of the sorted tailings is $1.06 \mathrm{wt} \%$ and the ratio of iron removal is $50.41 \%$, indicating most of titanomagnetite and limonite is removed. Therefore, the magnetic induction of 0.6 Tesla is more economical.

To remove the iron in kaolinite, redox method [9] [10] is attempted in the experiment. The $-10 \mu \mathrm{m},-7 \mu \mathrm{m}$ and $-5 \mu \mathrm{m}$ fractions of the tailings are obtained by settling method according to Stokes equation. The iron removal of the fine tailings is listed in Table 6.

The results in Table 6 show that the iron removal of the tailings by $\mathrm{H}_{2} \mathrm{O}_{2}$ treatment is insufficient in all the three fractions of the tailings, implying that most of Fe element is in the oxidized state. By using the $\mathrm{Na}_{2} \mathrm{~S}_{2} \mathrm{O}_{4}$ treatment, the Fe content of the $-7 \mu \mathrm{m}$ fraction changed from $1.68 \%$ to $1.27 \%$, which is equivalent to $25.4 \%$ removal, indicating that $\mathrm{Na}_{2} \mathrm{~S}_{2} \mathrm{O}_{4}$ method is the good way to the iron removal of the fine tailings.

\section{Conclusion}

The ion-adsorption rare earth mining tailings in Southern China can be re-utilized because kaolinite and quartz share $91.98 \mathrm{wt} \%$ of the tailing. The other minerals include feldspar, muscovite, biotite, titanomagnetite, limonite and ilmenite, which are the important raw materials in ceramic industry. The particle size distribution of the tailings is bimodal. $91.46 \mathrm{wt} \%$ of the $+0.4 \mathrm{~mm}$ fraction is quartz and the $-0.043 \mathrm{~mm}$ fraction is mostly kaolinite. The two minerals can be separated by sieves. The total Fe content of the tailings is $2.11 \mathrm{wt} \%$, which distributes

Table 5. Effect of the magnetic induction on the Fe content.

\begin{tabular}{ccc}
\hline \multirow{2}{*}{ Magnetic induction/ $\mathrm{T}$} & \multicolumn{2}{c}{$\mathrm{Fe}_{2} \mathrm{O}_{3}$} \\
\cline { 2 - 3 } & Grade/wt $\%$ & Ratio of iron removal/\% \\
\hline 0.2 & 1.40 & 34.78 \\
0.6 & 1.26 & 41.02 \\
0.8 & 1.06 & 50.41 \\
1 & 0.99 & 53.80 \\
Crude ore & 0.96 & 55.09 \\
\hline
\end{tabular}

Table 6. Iron removal of the fine tailings by redox method.

\begin{tabular}{cccc}
\hline & & $\mathrm{Fe}_{2} \mathrm{O}_{3}$ Content $/ \mathrm{wt} \%$ & \\
\cline { 2 - 4 } Tailings & Crude tailings & After $\mathrm{H}_{2} \mathrm{O}_{2}$ treatment & ${\mathrm{After} \mathrm{Na}_{2} \mathrm{~S}_{2} \mathrm{O}_{4} \text { treatment }}$ \\
$-10 \mu \mathrm{m}$ & 1.68 & 1.62 & 1.53 \\
$-7 \mu \mathrm{m}$ & 1.68 & 1.67 & 1.27 \\
$-5 \mu \mathrm{m}$ & 1.65 & 1.65 & 1.61 \\
\hline
\end{tabular}


mostly in titanomagnetite, kaolinite and limonite. The iron-bearing minerals can be removed by the periodic high-gradient magnetic separator with the magnetic induction of $0.6 \mathrm{~T}$. The Fe content of the sorted tailings is less than $1.06 \mathrm{wt} \%$, which meets the Chinese national standard of TC-3 grade for ceramic industry application. The $\mathrm{Fe}$ content in kaolinite can decrease further after $\mathrm{Na}_{2} \mathrm{~S}_{2} \mathrm{O}_{4}$ treatment.

\section{Acknowledgements}

The authors gratefully acknowledge the financial support provided by the National High-tech Research and Development Program of China (Grant No. 2012AA061903).

\section{References}

[1] Su, W. (2009) Economic and Policy Analysis of China's Rare Earth Industry. China Financial and Economic Publishing House, Beijing. (In Chinese)

[2] Chen, Z.H. (2011) Global Rare Earth Resources and Scenarios of Future Rare Earth Industry. Journal of Rare Earths, 29, 1-6.

[3] Wübbeke, J. (2013) Rare Earth Elements in China: Policies and Narratives of Reinventing an Industry. Resources Policy, 38, 384-394. http://dx.doi.org/10.1016/j.resourpol.2013.05.005

[4] Yang, X.J., Lin, A.J., Li, X.L., Wu, Y.D., Zhou, W.B. and Chen, Z.H. (2013) China's Ion-Adsorption Rare Earth Resources, Mining Consequences and Preservation. Environmental Development, 8, 131-136. http://dx.doi.org/10.1016/j.envdev.2013.03.006

[5] Guo, W. (2012) The Rare Earth Development Can No Longer Overdraw Ecological Cost. China Environment News, China Environmental Press, Beijing.

[6] Sylvester, P. (2012) Use of the Mineral Liberation Analyzer (MLA) for Mineralogical Studies of Sediments and Sedimentary Rocks. Mineralogical Association of Canada Short Course Series, 42, 1-16.

[7] Chen, L. (2011) Effect of Magnetic Field Orientation on High Gradient Magnetic Separation Performance. Minerals Engineering, 24, 88-90. http://dx.doi.org/10.1016/j.mineng.2010.09.019

[8] Svoboda, J. and Fujita, T. (2003) Recent Developments in Magnetic Methods of material Separation. Minerals Engineering, 16, 785-792. http://dx.doi.org/10.1016/S0892-6875(03)00212-7

[9] Zegeye, A., Yahaya, S., Fialips, C.I., White, M.L., Gray, N.D. and Manning, D.A.C. (2013) Refinement of Industrial Kaolin by Microbial Removal of Iron-Bearing Impurities. Applied Clay Science, 86, 47-53. http://dx.doi.org/10.1016/i.clay.2013.08.041

[10] Pham, A.L.T., Doyle, F.M. and Sedlak, D.L. (2012) Kinetics and Efficiency of $\mathrm{H}_{2} \mathrm{O}_{2}$ Activation by Iron-Containing Minerals and Aquifer Materials. Water Research, 46, 6454-6462. http://dx.doi.org/10.1016/j.watres.2012.09.020

[11] Santos, E., Scorzelli, R.B., Bertolino, L.C., Alves, O.C. and Munayco, P. (2012) Characterization of Kaolin from the Capim River Region—Brazil. Applied Clay Science, 55, 164-167. http://dx.doi.org/10.1016/j.clay.2011.11.009

[12] Chandrasekhar, S. and Ramaswamy, S. (2007) Investigation on a Gray Kaolin from South East India. Applied Clay Science, 37, 32-46. http://dx.doi.org/10.1016/j.clay.2006.11.007

[13] Xia, G., Lu, M., Su, X. and Zhao, X. (2012) Iron Removal from Kaolin Using Thiourea Assisted by Ultrasonic Wave. Ultrasonics Sonochemistry, 19, 38-42. http://dx.doi.org/10.1016/j.ultsonch.2011.05.008 